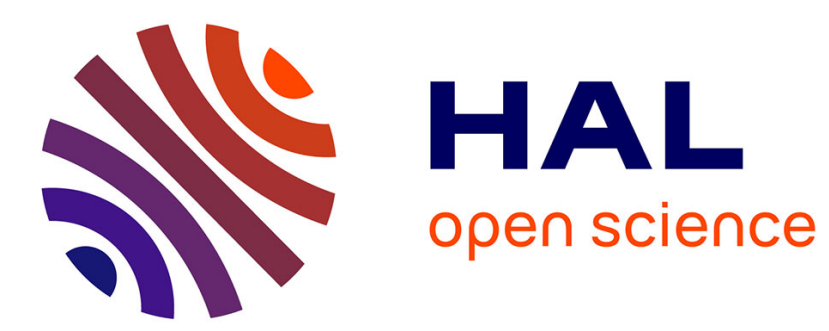

\title{
DIAGNOSTIC PAR DIFFUSION THOMSON D'UN PLASMA CHAUFFÉ PAR LASER
}

\author{
C. Stenz, E. Fabre
}

\section{To cite this version:}

C. Stenz, E. Fabre. DIAGNOSTIC PAR DIFFUSION THOMSON D'UN PLASMA CHAUFFÉ PAR LASER. Journal de Physique Colloques, 1973, 34 (C2), pp.C2-16-C2-16. 10.1051/jphyscol:1973205 . jpa-00215252

\section{HAL Id: jpa-00215252 https://hal.science/jpa-00215252}

Submitted on 1 Jan 1973

HAL is a multi-disciplinary open access archive for the deposit and dissemination of scientific research documents, whether they are published or not. The documents may come from teaching and research institutions in France or abroad, or from public or private research centers.
L'archive ouverte pluridisciplinaire HAL, est destinée au dépôt et à la diffusion de documents scientifiques de niveau recherche, publiés ou non, émanant des établissements d'enseignement et de recherche français ou étrangers, des laboratoires publics ou privés. 


\title{
DIAGNOSTIC PAR DIFFUSION THOMSON D'UN PLASMA CHAUFFÉ PAR LASER
}

\author{
C. STENZ et E. FABRE \\ Laboratoire de Physique des Milieux Ionisés, Ecole Polytechnique \\ Equipe de Recherche associée au CNRS, France
}

Résumé. - On étudie au moyen de la diffusion Thomson le chauffage par absorption d'un faisceau laser $\mathrm{CO}_{2}$, par un plasma au voisinage de la densité de coupure

$$
\left(8 \times 10^{18} \leqslant n_{\mathrm{e}} \leqslant 9 \times 10^{18} \mathrm{e} / \mathrm{cm}^{3}\right) .
$$

Le laser sonde utilisé est un laser à rubis dont la puissance crête est de $100 \mathrm{MW}$. Le spectre de la lumière diffusée à $90^{\circ}$ est analysé à l'aide d'un dispositif multicanal à 10 voies dont la résolution est de $13 \AA$ par canal. Dans ces conditions, et pour une température électronique du plasma cible de l'ordre de $10 \mathrm{eV}$, la valeur initiale du paramètre de diffusion $\alpha=1,05 \times 10^{-8}\left(n_{\mathrm{e}} / T_{\mathrm{e}}\right)^{1 / 2}$ est de l'ordre de 10, et la position des composantes satellites électroniques par rapport à la raie laser, donnée par $\Delta \lambda_{\mathrm{s}}(\AA) 1,44 \times 10^{-7} n_{\mathrm{e}}^{1 / 2}\left[1+2,7 \times 10^{16} T_{\mathrm{e}} / n_{\mathrm{e}}\right]^{1 / 2}$ est de l'ordre de $\pm 435 \AA$.

Une élévation de la température électronique, résultant du chauffage, comprise entre 50 et $100 \mathrm{eV}$, contribue à modifier $\alpha$ dont la valeur finale sera comprise entre 6 et 3 respectivement. Les composantes électroniques sont alors déplacées par rapport à leur position initiale d'une quantité de l'ordre de $25 \AA$ à $55 \AA$. Les modifications du spectre diffusé et notamment le déplacement des composantes électroniques permettront donc une mesure précise de l'élévation de $T_{\mathrm{e}}$.

Abstract. - We study by means of Thomson scattering, the heating of a plasma near the cutoff density by $\mathrm{CO}_{2}$ laser beam absorption.

Using a multichannel spectral Analyzer ( 10 channels, $13 \AA$ spectral resolution per channel) the scattered light is observed at right angles to the beam from a $100 \mathrm{MW}$ Q-ruby laser focused in the center of the target plasma. At cutoff density and an electron temperature of $10 \mathrm{eV}$, the initial value of the scattering parameter $\alpha$ is of the order of 10 , and the electron satellite lines are spaced close to $\pm 435 \AA$ from the incident laser wavelength. As a result of heating, the electron temperature increases from an initial value of 10 to a final value between 50 and $100 \mathrm{eV}$, and $\alpha$ changes from 10 to a value between 3 and 6 .

The electronic components are then shifted from their initial position by a quantity ranging from $25 \AA$ to $55 \AA$.

The modification of the spectral distribution of the scattered light and specially the position of the electron satellite lines will give a measurement of the electron temperature increase. 